\title{
Eco Restoration of River Coovum in India
}

\author{
S.Bharathidasan ${ }^{1}$, T. K. Krushnadesikan ${ }^{2}$, K. Arun $^{3}$, A. AbdulRahman ${ }^{4}$ \\ 1,2,3 (Department of Civil Engineering, Sri Sai Ram Engineering College, Chennai-44, India ) \\ ${ }^{4}$ (Department of Mechanical Engineering, Sri Sai Ram Engineering College, Chennai-44, India)
}

\begin{abstract}
There are about 14,972 families living in 65 slums along Coovum River in India. Hence, there has been huge accumulation of solid waste in the form of bio sludge. Water Hyacinth (Eichhornia crassipes) grown luxuriously in the Coovum river, causes ecological and economic problems. They reduce the gaseous exchange that takes place at the air/water interface and it also reduces the photosynthetic activity of submerged plants. Experts in the field believe that it is difficult to eradicate the water hyacinth and the bio sludge, since the conditions that allow it to proliferate are not being controlled.

The cost of petroleum products and electricity are very high considering the low level of economic activity. Thus, by utilising the Coovum bio-sludge and the water hyacinth, the biogas can be generated, which can be used as a source for heating and lighting purposes.

The bio sludge accumulated in the bottom of the River Coovum will be dredged using sludge pump. The collected sludge will be processed to remove debris and other waste materials other than organic components of the sludge. The processed bio sludge will be fermented using anaerobic bacteria. However, the anaerobes are already present in the bio sludge, yet it may not yield good result of production of biogas, hence we plan to produce the anaerobic bacteria in order to have sufficient sustained anaerobic bacteria in the system. Hence, it is proposed to use the cow-dung separately in a container and after proper fermentation, this will be added to the Coovum sludge and biogas production will be monitored. Further, using the same process it is planned to collect the water hyacinth and by using the yeast for fermentation, the fermented hyacinth will be combined with the bio sludge. By the process, it is proposed to produce the biogas continuously to enable to make use of the sludge and water hyacinth as raw materials which are available in plenty in the River Coovum.

The Coovum bio sludge and water hyacinth will provide energy source as bio gas for heating during day light and light during night. The removal sludge will in course of time improve water quality and environmental hygiene. The bio sludge once dredged, the water holding capacity will be increased by flushing either sea water or storm water during rain and domestic treated water will flow freely without stagnation and will pave way for navigation. Utilizing treated waste water for fodder development and channel grass as phytoremediation of effluent will be the outcome of the project. This will increase the socio economic condition of the people beside ecological improvement of Coovum River.
\end{abstract}

Keywords: Biogas, Bio sludge, Cow dung, Eichhornia crassipes, River Coovum, Yeast.

\section{Introduction}

It is reported that the work on integrated Coovum river eco restoration plan is to be implemented over five years (The Hindu, dated April 30,2014).There are 14,972 families live in 65 slums along Coovum river ,hence there has been huge accumulation of solid waste in the form of bio sludge. Sewage sludge containing sodium chloride and urea as major constituents, and with macronutrients such as calcium, potassium, magnesium sulphate and phosphate as minor constituents. It is free from hazardous chemical compounds or heavy metals. The total quantities of nutrients in sewage sludge are significant (about $80 \%$ of the nitrogen, $50 \%$ of the phosphorous and $60 \%$ of potassium) when compared to the quantities of nutrients in the mineral fertilizers used in agriculture.

Since the Coovum river is found to be rich in nutrients and therefore eutrophication which results in the luxurious growth of water hyacinth in the selected places of Coovum River. It is known that water hyacinths cause ecological and economic problems by impeding navigation and fishing activities, clogging irrigation systems and by creating a chronic shortage of dissolved oxygen harmful to the fauna and the flora (Seehausen et al, 1997; Malik, 2006). Perna and Burrows (2005) noted that the water hyacinth covers on water bodies reduce the gaseous exchanges that take place at the air/water interface and reduce the photosynthetic activity of submerged plants by hindering the penetration of the sun rays.

The convention on Biological Diversity, in its article $8(\mathrm{~h})$, recommends that each contracting party take measures to prevent the introduction of exotic species and to control or to eradicate those that threaten ecosystems, habitats or species. The efforts expended by communities have not succeeded in eradicating the water hyacinth.

Experts in the field believe that it is difficult to eradicate the water hyacinth, since the conditions that allow it to proliferate are not being controlled (Howard and Matindi, 2003). 
The cost of petroleum products and electricity are very high considering the low level of economic activity. Therefore, the utilization of Coovum bio sludge and water hyacinth biomass to produce energy for modern use represents a good opportunity and a credible alternative.

It is reported that water hyacinth are very rich in hydrocarbons, which is essential for production of methane (Dr.Veerababu, The Times of India, February 11, 2013).

River Coovum has played a vital role in religious and historical events. In view of this it is proposed to converting the river into a clean water way (Venkatesh Ramakrishnan, The Hindu, June 17, 2014)

\section{Objectives}

(a) To environmentally upgrade the River Coovum by removal of sludge and use the sludge and water hyacinth to meet collective energy needs for generating biogas and to make use of the biogas for heating and lighting purpose for the domestic need of Coovum residents.

(b) The byproducts of biogas plant will be utilized as manure and as water source for greenery. The sand and soil separated from the sludge will be used for landfills.

(c) Optimisation of biogas production at pilot scale level.

\subsection{Bio gas production using Coovum bio sludge:}

\section{Methodology}

The bio sludge accumulated in the bottom of the River Coovum will be dredged using sludge pump. The collected sludge will be processed to remove debris and other waste materials other than organic components of the sludge.

The processed bio sludge will be fermented using anaerobic bacteria. However, the anaerobes are already present in the bio sludge, yet it may not yield good result of production of biogas, hence we plan to produce the anaerobic bacteria in order to have sufficient sustained anaerobic bacteria in the system.

Hence, it is proposed to use the cow-dung separately in a container and after proper fermentation, this will be added to the Coovum sludge and biogas production will be monitored.

Sewage sludge containing sodium chloride and urea as major constituents, and with macronutrients such as calcium, potassium, magnesium sulphate and phosphate as minor constituents. Hence, it is proposed to use the nutrients for the bio gas production as it is rich with anaerobic bacteria which influence the bio gas production.

\subsection{Bio gas production using water hyacinth:}

Further, using the same process it is planned to collect the water hyacinth and by using the yeast for fermentation, the fermented hyacinth will be combined with the bio sludge. By the process, it is proposed to produce the biogas continuously to enable to make use of the sludge and water hyacinth as raw materials which are available in plenty in the River Coovum.

Urban agriculture is quickly will become a new paradigm in food production and therefore the food security and it has the potential of creating this past economy in tens of millions of new jobs within the next decade. Water hyacinth (Eichhornia crassipes (Mart.) Solms) grows luxuriously in the Coovum waste water is the raw material could be utilized for biogas production irrespective of the fact that the plants are grown under higher or lower nitrogen concentrations and there is no necessity for the $\mathrm{C} / \mathrm{N}$ ratio to be within optimum range for anaerobic digestion. Further, it is concluded that several biochemical characteristics of the substrates significantly influences biogas production besides the $\mathrm{C} / \mathrm{N}$ ratio (Jayaweeraet al 2007, Almoustapha et al 2009).

\subsection{Fabrication and installation of biogas plant:}

It is proposed to fabricate 1 metric cube biogas plant using syntax tanks. By using sludge pump, the bio-sludge in the bottom of Coovum River will be removed and processed for producing biogas. Similar method will also be employed for the water hyacinth which is present in an extensive area of Mogappiar, Chennai as a source of raw material.

The Bio-sludge and water hyacinth will be collected and processed and fermented and will be used to produce biogas. It is proposed as a pilot plant to use the biogas for heating and lighting purposes and the byproduct will form as source of manure for kitchen garden. 
IV. Location Details:

Project Location and Area River Coovum bank, Mogappiar, Chennai is shown below.
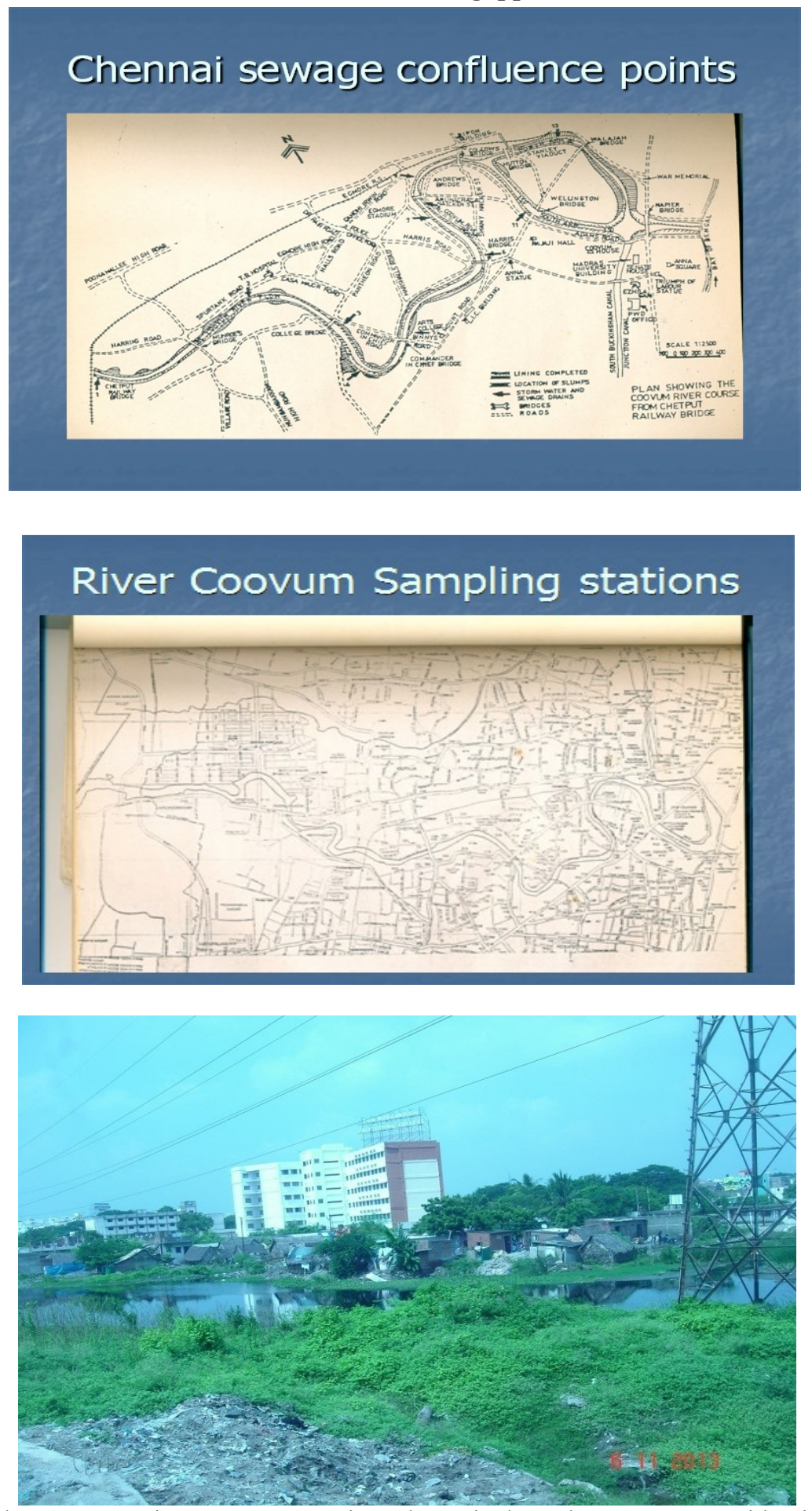

Fig.1. A view of the Coovum river near Mogappiar, Chennai where the Coovum residential Colony (in huts) exists contrasting multi-storied complex is seen. Raw sewage is discharged causing prolification of water hyacinth and other weeds. 


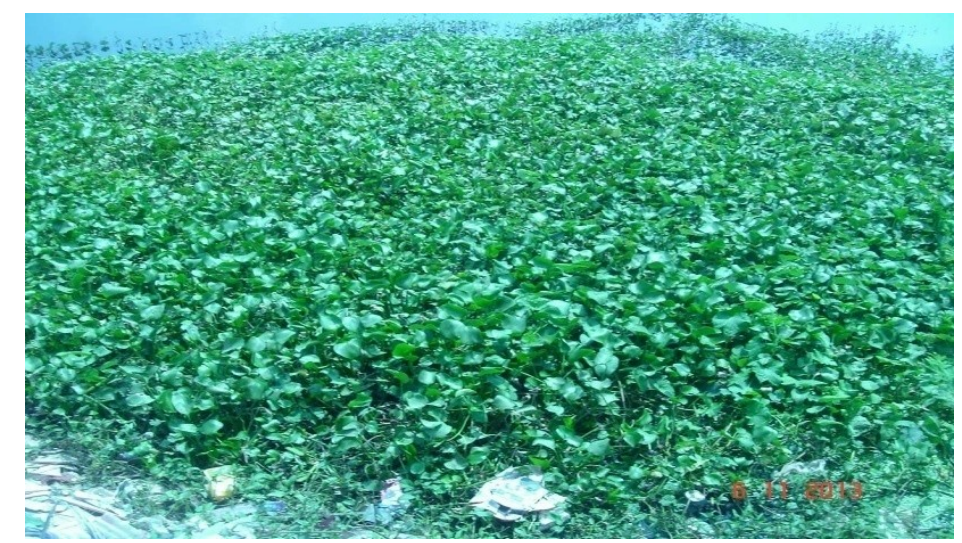

Fig.2. The water hyacinth (Eichhornia Crassipes) luxuriant growth on the brink of Coovum River in the chosen site of residents of Coovum.

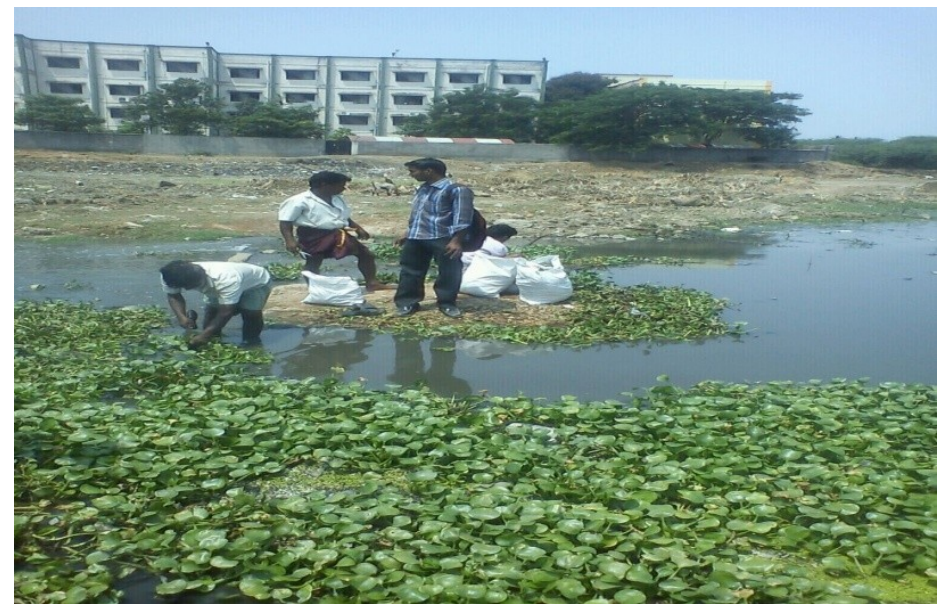

Fig.3. The collection of water hyacinth from the Coovum River for the production of biogas.

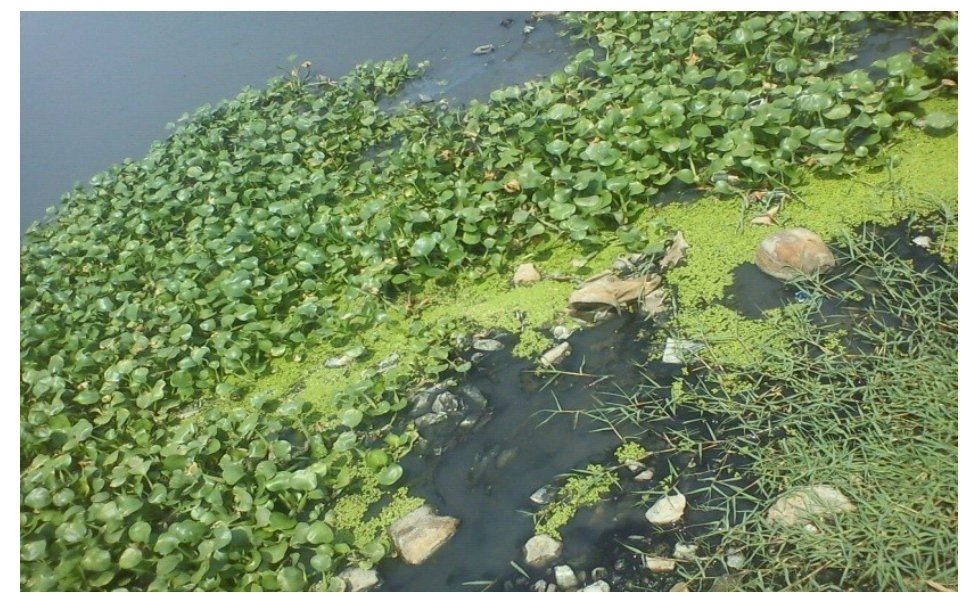

Fig.4.The confluence of sewage, leachets of inorganic and other wastes get stagnated causing accumulation of solid waste as sludge in the river bottom.

\subsection{Outputs from the project:}

\section{Conclusion:}

The Coovum bio sludge and water hyacinth will provide energy source as bio gas for heating during day light and light during night. The removal sludge will in course of time improve water quality and environmental hygiene. The bio sludge once dredged, the water holding capacity will be increased by flushing either sea water or storm water during rain and domestic treated water will flow freely without stagnation and will pave way for navigation .By utilizing the sludge as a source of bio energy the socio economic condition of the residents of Coovum will be improved. Utilizing treated waste water for fodder development and channel grass as phytoremediation of effluent will be the outcome of the project. This will increase the socio economic condition of the people beside ecological improvement of Coovum River. 


\subsection{Benefits:}

\subsubsection{Social Benefits:}

The sludge once treated and converted into a fertilizer will not pollute the ground water. The environmental problem such as mosquito menaces other breeding of flies are completely avoided. The cost of fertilizers is economical because of treating the sludge and recovering the nutrients and converting the sludge into fertilizer are done at the site itself to bring down the cost of the product and saves transportation of raw materials for processing. Fertilizer will be applied to crops and plants and it is known that organic manure increases the productivity and enhances the soil health.

\subsubsection{Economic Benefits:}

Apart from producing biogas energy, the digested sludge contains nutrients and it is economical to recover the nutrients for cultivation of plants. The cost of production of nutrients is economical when compared to the cost of fertilizer such as urea and super phosphate. The man power required for maintaining the fertilizer plants and converting sludge into a fertilizer are within the specified requirement.

The manure produced by this technology is non-hazardous, safe, ecologically sound and economically viable and increases the overall productivity of the product. There is no odour, neither it contains any pathogens and is considered an effective organic fertilizer.

\subsubsection{Beneficiary Tie-up:}

Once the technology is standardised this will be transferred to the end users through Tamilnadu Drainage and Water Supply Department, NGOs and women Self Help Group. It is proposed to make use of the biogas for house hold purposes towards heating during the day and make use of the energy for lighting purpose during night. The residents of Coovum will also be involved in the project as beneficiary to utilise the biosludge from the biogas plant as manure to develop kitchen garden.

\section{References}

[1] O.Almoustapha, S.Kenfack and J.Millogo - Rasolodimby: Biogas production using water hyacinths to meet collective energy needs in a Sahelian country

[2] Kumar, S. : Studies on efficiencies of bio-gas production in anaerobic digesters using water hyacinth and night soil alone as well as in combination, Asian J.Chem.,17,934-938,2005.

[3] Kivaisi, A. K. And Mtila, M: Production of biogas from water hyacinth (Eichhornia crassipes)(Mart) (Solms) in a two stage bioreactor, World J.Microb.Biot., 14,125-131,1998.

[4] Seehausen et al, 1997; Malik, 2006:

[5] Dr. Veerababu, Times of India, February 11, 2013

[6] Perna and Burrows (2005).

[7] Venkatesh Ramakrishnan, The Hindu, June 17, 2014

[8] Malik, A.: Environmental challenge vis a vis opportunity: The case of water hyacinth, Environ. Int., 33, 1,122-138, 2007 